Pakistan Journal of Humanities and Social Sciences

April - June 2019, Volume 7, No. 2, Pages 257-265

\title{
Strategies of Green Marketing as tool of Competitive Advantage
}

\author{
Arslan Afzal Ansari ${ }^{1}$, Muhammad Waqas Ameer ${ }^{2}$, Lubna Tabbassum ${ }^{3}$ \\ ${ }^{1}$ Deputy Registrar - Sub Campuses (BWP, MUL, RYK), National College of Business \\ Administration and Economics, Lahore \\ ${ }^{2}$ Assistant Professor, National College of Business Administration \& Economics, Bahawalpur \\ ${ }^{3}$ Banking Service Manager, Allied Bank Ltd., Pakistan \\ Email: arslanansari@hotmail.com waqas.usm@gmail.com
}

\begin{abstract}
This paper aims to find out the impact of green marketing strategies as tool of competitive advance for the firm. Green marketing is a basic tool and marketing strategy to get competitive advantage on other firms in the market. The firms which are going green are enjoying high returns and a great increase in their profits. Moreover these firms also have competitive advantage on other firms in the market.
\end{abstract}

Keywords: Green marketing, Competitive advantage

\section{Introduction}

A process of globalization is continuously spreading over the world, which is opening more new markets for both consumers and buyers with further alternatives to buy and sell. Where globalization has positively impact for buyers and sellers, on the other hand, it is also going to create some new challenges and problems for a world. Environmental problem is one of the main problems of globalization which affects all living beings. Today`s consumer have serious concerns about the world's future. As various studies shows that now consumer and corporations are more anxious and preferring to purchase environment friendly products to prevent world`s environment from the threat to living being. Companies are adapting change and preparing their strategies according to the desires of the consumers, specially, those who have serious concerns about the environmental problems in the world.

Today, a term using for friendly environment products are "Green Products" and the strategies for their advertisement and marketing are known as "Green Marketing". "Green Marketing is a marketing strategy that companies use to market their products taking into consideration all the factors e.g. pricing policies of a company, promotions, features of products and distribution activities and advertisement strategies to gain share of potentials consumers". 
A good manager believes that consumer's belief about environmental issues must be considered on priority to attain objectives of the marketing strategies. Traditionally, companies were engaged to prepare their marketing strategies with the prior objective of profitability and consumer retentions. Before proceeding to the selecting and producing the environmentally friendly products, it is essentially required to integrate into the corporate culture.

According to many other researchers, "green marketing is about the studies regarding negative and positive impact on environmental pollution, Energy consumption and consumption of other resources as a result of Marketing (Cevreomen 2010, as cited in Aysel, 2012)", Another elucidate green marketing as "Green Marketing serve two purpose (Uydaci 2002).

Today, a movement of going green is getting more popularity in the world that reshapes the organizations strategies of marketing and productions. World`s natural resources are not enough to fulfill the unlimited wants. Companies are more concerned about the energy efficiencies and products to make environment friendly and less harmful. The practice, called green washing: "disinformation on the environmental care accuracy (Laufer, 2003)". "Montiel and Ramus (2005) explained green washing as resulting by the fact that companies are not required by law to publish environmental policy statements or to verify if these statements are true, by using independent third parties". But when we talk about strategies of green marketing, it remained a key factor to gain a competitive advantage.

Due to the lack of awareness of Green products / Eco logical products and green labels placed on the products, firms are facing problem to implement their green products strategies to achieve their ultimate objectives of profitability and consumer retentions.

\section{COMPETITIVE ADVANTAGE AND STRATEGIES}

This study is based on two major pillars i.e. Green strategies and Competitive advantage. To answer the question of the research/study, both terms need to explain here:

\section{A. What is Competitive Advantage?}

A Competitive advantage is a competitive position where organizations seek more profit than its competitors. Competitive advantage involves three strategies through which organizations seek competitive advantage through its strategies i.e. Price, differentiation and quality. 
These strategies will be explained later. Another definition of competitive advantage is explained as; "an advantage that a firm has over its competitors, allowing it to generate greater sales or margins and/or retain more customers than its competition".

The two main types of competitive advantage are: Price Comparative advantage and differential advantage. A comparative advantage represent firm`s ability to produce a goods or services as low cost than its competitors to gain an advantage to sell at low price in the market and generate more profits as compare to its competitors. While on the other hand, Differential advantage created when firms differentiate its products and services to attract customers to gain an advantage on its competitors. A differential advantage is created on the base on product differentiation.

"Competition is at the core of the success or failure of firms (Porter, 1985, p. 1)." According to Coda, Minoja and Zollo, if a company is fail to gain a competitive advantage but offer a quality product and services that add value to its customer will ultimate face a loss of share in the market. When Organizations face these kinds of problems, only few choices left including cutting prices and profit margins to keep themselves in the market, otherwise, in resultant of a loss, a complete exit from the market can be faced. This is a reason that every organization should have competitive advantage.

\section{IMPORTANCE OF GREEN MARKETING}

Currently in the world, we have limited resources left on the earth which is not enough to fulfill the unlimited wants of the world. A wide range of debate is still in progress that "whether the earth is a resource at man's disposal". In the free market economies where a consumer has freedom of choice, it has been acknowledged that every individuals and organizations do have a right to fulfill their wants. Due to unlimited wants, firms develop new and alternate strategies to make their customer retain and more satisfy to enjoy maximum profits.

Some important reasons are as follow: 
1. Organizations use strategies of green marketing as to compete with their competitors to gain a competitive advantage to achieve ultimate goals of an organization.

2. Organizations feel their social responsibility to protect environment.

3. A competition between firms force them to adopt environmental marketing activities.

\section{Purpose}

Purpose of this study is to find out the impact of green marketing strategies as tool of competitive advance for the firm. In order to find out the competitive advantage process of green marketing, a study of different organizations has been conducted to evaluate the impact of green strategies, ecological products, green labeling and environment friendly products on firm's efficiency and output as competitive advantage.

The Companies expanding their competitive advantage being green to compete its competitors. Some of the companies detail is mentioned here;

\section{A. Bank of America}

Bank of America has realized that the green product/eco-friendly procedure can be applied along with business growth. The company started it recycling of papers and reduced paper use by $32 \%$ that saved 200,000 trees for each year's. The bank also offered reward to its employee on buying hybrid vehicles.

\section{B. General Electric}

Another example of General Electric. GE has sold its product called Ecomagination products that also includes solar panels and other electrical items of worth $\$ 12$ Billion. The company also engage to make a headway to clean up the area where its wastage material gone into the river Hundson.

\section{Dupont}

Another famous company who is seriously involved to going green.

The company has taken serious steps to make this operation sustainable. Company has 
hired a professional as advisor. Company has already put it great efforts to reduce its emissions during 90 `s by $63 \%$.

\section{McDonalds}

McDonalds, a popular fast -food chain, working around the world shifted its operations towards green strategies because today people are going greener. Today`s customers are getting aware of green products and services that shaped major companies to shift their working environment more ecofriendly. McDonald is one of them and now working close in collaboration with PETA to make its operations and strategies more human and environment friendly.

\section{E. Home Depot}

Home Depot is famous and producing old-growth wood products. A rainforest network has taken an action against that company to reduce its product to save green environment. A procession of people came outside their homes in front of home depot retail stores around the nation. In the start, company resist against the action, but when they received calls and letter, an estimated figure was 45,000, the directors of the home depot decided not to harvest trees from old-growth rainforest.

\section{F. Starbucks}

Starbucks, a world-renowned organization has adopted to be greener. A name of the approach the company has used was "bean-to-cup" approach. A company used to recycle papers and save about 78,000 tree per years to make a coffee cup sleeve. A company has been partnered with many other organizations working for ecological environment.

\section{G. Wal-Mart}

Wal-Mart considering in the list of those who hate green movement in the entire world. Wal-Mart has already launched its long-term plan to make their operations more friendly and sustainable by utilizing its waste material to convert into the renewable energy by $100 \%$. 


\section{H. Coca-Cola}

Coca-Cola is engaged in the effort to make environment green. An objective of the company to save environment is water, sustainable packaging, and climate \& energy protection. A company also engaged in the community programs of recycling of different items.

\section{Toyota}

Toyota company has offered its most environment friend product TOYOTA "PRIUS", the world's first mass market hybrid vehicle. It is more fuel-efficient car available for sale almost all in the world especially in UK, a car ranked third least carbon-emitting in a county.

\section{J. Dell}

With the advancement in the technology, especially if we talk about

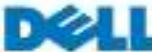
the computer equipment which wastage is most difficult and quite costly to dispose of because the parts used in the mother boards and in other parts of computer equipment. By introducing "no computer should go to waste" recycling HONDA program, Dell announced that customers can return its branded products back to the company. Dell also has started its program to help other companies to dispose of their products.

\section{K. Honda}

Honda is one of the major giants whose contribution is really appreciate able. Honda considering as more fuel-efficient company in US. Honda has worked hard to make hydrogen fuel cell and still working on to create entire infrastructure for hydrogen in the future.

\section{Review studies}

The environmental conditions these days are getting worst day by day due to increase in production of goods. The firms are throwing its waste in environment in the form of industrial wastage and smoke and many other dangerous gasses and chemicals. All this causes serious damages to the human being. Therefore, now a days consumer are focusing on the use of green products. Consumers are highly concerned with the protection of environment. The business should focus on new environment friendly 
technology and business executives should pay attention on the arrangement of seminars and workshops for the consumers to aware them to the green products and their benefits for the environment. If the consumers are well awarded by the green products then they tend to buy more green products, which results in competitive advantage for a firm. (Juwaheer, Pudaruth and Noyaux, 2012).

According to Yazdanifard, Rashad, \& Mercy (2011), in their study "The impact of Green Marketing on Customer satisfaction and Environmental safety", green marketing is very important tool for a firm which is going green for the protection of environment. Now a days many firms are going green and due to which a new market has taken place, which is known as green market. All these firms which are going green need to have more effective green marketing policies to survive in the market. Green marketing is not just a marketing strategy but also an environmental protection tool.

Spicer (1978) analyzed 18 pulp and paper companies from COMPUSTAT and CEP found that the environmental conditions are very important factor in high returns of a firm. A firm which does not focuses on environmental conditions faces high risks and lower returns.

Shane and Spicer (1983) studied the pulp and paper, iron and steel, electric power and petroleum industries using CRSP financial tapes and CEP pollution performance data and analyzed that the investors are focusing on the future cash flows. The reason of this is the negative environmental disclosures.

According to Jaggi and Freedman (1992), In short run the relationship between environmental performance and financial performance is very week. This was found in study of BOD, TSS and Ph levels from the data of 13 firms of pulp and paper mills and financial data from COMPUSTST.

Klassen and McLaughlin (1996) searched the environmental award winner firms and firms with environmental crises from the Nexis and UPI databases and found that when a firm focused on environmental conditions and won an environmental award, its stock value was increased by 80.5 million dollars on average. 
Nehrt (1996) studied 50 chemical bleached paper pulp manufacturers in Brazil, Canada, Finland, Portugal, Spain, Sweden and the U.S. he found that the firm will get financial advantage if it invests in cost reducing and pollution reducing technologies.

\section{Conclusion}

This study concludes that the consumers now a days are very conscious about the protection of environment for their future generations. By adopting environmentally friendly technologies and policies many companies are going green now a days. The firms which are implementing go green policies by all their business aspects are getting competitive and financial advantage on other firms in the green market. Firms should focus more on their green policies and green marketing tools to enhance their returns significantly.

\section{References}

Boztepe, A. (2012). Green marketing and its impact on consumer buying behavior. European Journal of Economic \& Political Studies, 5(1), 5-21.

Devi Juwaheer, T., Pudaruth, S., \& Monique Emmanuelle Noyaux, M. (2012). Analysing the impact of green marketing strategies on consumer purchasing patterns in Mauritius. World Journal of Entrepreneurship, Management and Sustainable Development, 8(1), 36-59.

Jaggi, B., \& Freedman, M. (1992). An examination of the impact of pollution performance on economic and market performance: pulp and paper firms. Journal of Business Finance \& Accounting, 19(5), 697-713.

Klassen, R. D., \& McLaughlin, C. P. (1996). The impact of environmental management on firm performance. Management Science, 42(8), 1199-1214.

Laufer, W. S. (2014). Corporate social accountability and greenwashing. Journal of Business Ethics, 43(3), 253-261.

Nehrt, C. (1998). Maintainability of first mover advantages when environmental regulations differ between countries. Academy of Management Review, 23(1), 77-97.

Ramus, C. A., \& Montiel, I. (2005). When are corporate environmental policies a form of greenwashing?. Business \& Society, 44(4), 377-414. 
Shane, P. B., \& Spicer, B. H. (1983). Market response to environmental information produced outside the firm. The Accounting Review, 58(3), 521-538.

Spicer, B. H. (1978). Investors, corporate social performance and information disclosure: An empirical study. Accounting Review, 53(1), 94-111.

UYDACI，M. (2002). YeG̣il Pazarlama-GGG Ahlâkı ve Çevresellik Açısından YaklaG̣ımlar. Türkmen Kitabevi, Gstanbul.

Yazdanifard, R., \& Mercy, I. E. (2011, January). The impact of green marketing on customer satisfaction and environmental safety. In 2011 International Conference on Computer Communication and Management (Vol. 5, pp. 637641). 